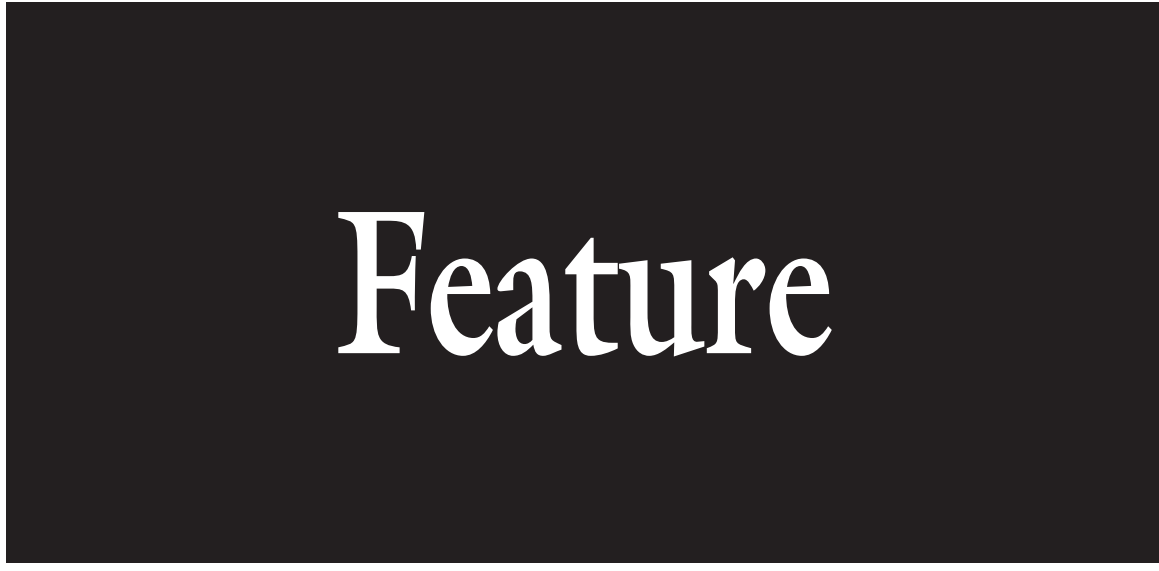

\title{
Horticultural Applications of a Newly Revised USDA Plant Hardiness Zone Map
}

\author{
Mark P. Widrlechner ${ }^{1,5}$, Christopher Daly ${ }^{2}$, Markus Keller ${ }^{3}$, \\ and Kim Kaplan ${ }^{4}$
}

AdDITIONAL INDEX wORDs. winter injury, zip code, GIS, minimum temperature, Vitis, climate

SUMMARY. The accurate prediction of winter injury caused by low-temperature events is a key component of the effective cultivation of woody and herbaceous perennial plants. A common method employed to visualize geographic patterns in the severity of low-temperature events is to map a climatological variable that closely correlates with plant survival. The U.S. Department of Agriculture Plant Hardiness Zone Map (PHZM) is constructed for that purpose. We present a short history of PHZM development, culminating in the recent production of a new, highresolution version of the PHZM, and discuss how such maps relate to winterhardiness per se and to other climatic factors that affect hardiness. The new PHZM is based on extreme minimum-temperature data logged annually from 1976 to 2005 at 7983 weather stations in the United States, Puerto Rico, and adjacent regions in Canada and Mexico. The PHZM is accessible via an interactive website, which facilitates a wide range of horticultural applications. For example, we highlight how the PHZM can be used as a tool for site evaluation for vineyards in the Pacific northwestern United States and as a data layer in conjunction with moisture-balance data to predict the survival of Yugoslavian woody plants in South Dakota. In addition, the new map includes a zip code finder, and we describe how it may be used by governmental agencies for risk management and development of recommended plant lists, by horticultural firms to schedule plant shipments, and by other commercial interests that market products seasonally.

$\mathrm{H}$ orticulturists have long recognized that the accurate prediction of winter injury is a key component of the effective cultivation of long-lived woody and herbaceous perennial plants in many climates. Winter injury can limit long-term plant survival and vigor and can reduce production of valuable horticultural products, including flowers, foliage, fruit, and seeds. As noted by Skinner (1962), "frost dates, length of the growing season, and minimum winter temperatures are among the least readily controlled of the major factors governing the geographic adaptability of plants," so the ability to forecast the risks associated with such factors is extremely valuable.

Freeze injury to various plant tissues and organs typically occurs at three stages in the annual cycle (Larcher, 2005; Raulston and Tripp, 1994): 1) During the autumn, when plants cease growth (Kalcsits et al., 2009) and begin to harden or acclimate to winter conditions (often signaled by decreasing photoperiod and temperature), early, low-temperature events can exceed a plant's (or a specific tissue's) ability to withstand the event. 2) During the lowest temperatures of midwinter, when plant tissues optimally achieve a maximal degree of cold acclimation, extreme low-temperature events may still overwhelm adaptive survival mechanisms. 3 ) And finally, during the late winter and early spring, plants may deharden when exposed to temperatures above freezing, having satisfied physiological rest requirements (Litzow and Pellett, 1980), and can then suffer damage from subsequent lowtemperature events.

Studies that thoroughly document the seasonal progression of acclimation and provide graphical representations of the timing of actual or potential injury from low-temperature events at all three stages in the annual cycle include those by McNamara et al. (2002), McNamara and Pellett (1993), Mills et al. (2006), Scheiber et al. (2002), Schrader and Graves (2003), Szalay et al. (2010), and Väinölä et al. (1997).

\section{Hardiness-zone basics}

Of the three stages when injury often occurs, the frequency and severity of midwinter, low-temperature events have historically received considerable attention by plant scientists. Specific weather events causing plant injury on a case-by-case basis may yield insights on factors influencing adaptation [see Bachtell and Green (1985) for an example from the Chicago region and Gu et al. (2008) for a detailed discussion of the Spring 2007 freeze in the eastern and central United States], but such weather events are not repeatable and do not lend themselves to experimentation and hypothesis testing. However, further insights can be gained by shifting emphasis away from individual weather events (or even seasons) to longer time frames that document multiple, extreme events on a climatic scale. Heinze and Schreiber (1984) presented a comprehensive review of this topic, detailing the history and application of long-term climatological data to relate patterns of woodyplant adaptation to low-temperature injury.

A BRIEF HISTORY OF HARDINESS ZONES AND ZONE MAPS. A relatively simple method used to visualize geographic patterns of the biological severity of low-temperature events is to map a climatological variable that closely correlates with patterns of plant survival. Rehder (1927) developed the first such map for the United States, with a mapped zonation system that 
related winter minimum temperatures to the survival of specific woody plants. He roughly divided the temperate portion of the conterminous United States and southern Canada into eight zones based on the mean temperature of the coldest month, each zone spanning $2.8^{\circ} \mathrm{C}\left(5^{\circ} \mathrm{F}\right)$.

Shortly thereafter, Kincer (1928) produced a similar map, but based instead on "the mean annual extreme minimum temperature" [the lowest temperature recorded in 1 year-herein referred to as the plant hardiness $(\mathrm{PH})$ statistic], scaled by $5.6^{\circ} \mathrm{C}\left(10^{\circ} \mathrm{F}\right)$ intervals. Although he made this change without the benefit of extensive data demonstrating the superiority of extreme low-temperature events, recently Quamme et al. (2009) presented a 90-year dataset from the Okanagan Valley, BC, Canada, that verified a strong association between such events and winter injury for a wide range of fruit crops.

In 1936, a slightly different approach was taken by Wyman [U.S. Department of Agriculture (USDA), 1936], who also produced a revised plant hardiness map for the United States, this time based on the $\mathrm{PH}$ statistic averaged over the years 1895-1935. However, one limitation with the 1936 map was that its zones were not based on consistent temperature intervals; some were $2.8^{\circ} \mathrm{C}\left(5^{\circ} \mathrm{F}\right)$, whereas others were $5.6^{\circ} \mathrm{C}\left(10^{\circ} \mathrm{F}\right)$ or $8.3^{\circ} \mathrm{C}\left(15^{\circ} \mathrm{F}\right)$. This map and

This journal paper of the Iowa Agriculture and Home Economics Experiment Station, Ames, Iowa, Project No. 1018, was supported by USDA-ARS Research Project 3625-21000-053, Hatch Act and State of Iowa funds, and a Specific Cooperative Agreement between the USDA Agricultural Research Service and Oregon State University.

We thank Peter Bretting, Candice Gardner, William Graves, Rita Hummel, S. Elwynn Taylor, and three anonymous reviewers for providing valuable comments and suggestions for improving the manuscript; Michael Wisniewski for assistance in supplying useful references; and Mike Halbleib for assistance with graphics.

Mention of commercial brand names does not constitute an endorsement of any product by the USDA or cooperating agencies.

${ }^{1}$ USDA-ARS, North Central Regional Plant Introduction Station, IA State University, G212 Agronomy Hall, Ames, IA 50011 (retired)

${ }^{2}$ PRISM Climate Group, 2000 Kelley Engineering Center, Oregon State University, Corvallis, OR 97331

${ }^{3}$ Irrigated Agriculture Research and Extension Center, Washington State University, 24106 North Bunn Road, Prosser, WA 99350

${ }^{4}$ USDA-ARS, George Washington Carver Center, 5601 Sunnyside Avenue, Beltsville, MD 20705

${ }^{5}$ Corresponding author. E-mail: isumw@iastate.edu. subsequent updates using more recent meteorological data appeared in various publications in 1951, 1967, and 1971 (Wyman and Flint, 1985).

This lack of uniformity in zone intervals prompted the USDA Agricultural Research Service (ARS) to develop its own "Plant Hardiness Zone Map" with zones defined uniformly by differences in the $\mathrm{PH}$ statistic of $5.6^{\circ} \mathrm{C}\left(10^{\circ} \mathrm{F}\right)(\mathrm{USDA}, 1960$, 1965). Discrepancies between the zone designations of Wyman's and USDA's maps caused some confusion (Skinner, 1962), but the USDA's consistent zone designations became the standard for assessing plant hardiness in the United States with the release of a comprehensive PHZM update in 1990 (Cathey, 1990).

The 1990 version of the PHZM was based on the PH statistic for the United States, Canada, and Mexico (Cathey, 1990; Cathey and Heriteau, 1990). The map included ten $5.6^{\circ} \mathrm{C}$ $\left(10^{\circ} \mathrm{F}\right)$ zones; zones $2-10$ were subdivided into $2.8^{\circ} \mathrm{C}\left(5^{\circ} \mathrm{F}\right)$ half zones (Table 1 ). Zone 11 was introduced to represent areas with $\mathrm{PH}>4.4{ }^{\circ} \mathrm{C}$ $\left(40^{\circ} \mathrm{F}\right)$ that are essentially frost-free. Even in parts of the world that do not normally experience freeze events or a well-defined winter season, plants can experience chilling injury at temperatures below about $10^{\circ} \mathrm{C}\left(50^{\circ} \mathrm{F}\right)$ (Levitt, 1980). Thus, knowledge about geographic patterns of "warmer" lowtemperature extremes is also horticulturally valuable in frost-free regions and can provide guidance in colder regions on how best to manage the outdoor cultivation of tender plants that experience chilling injury.

Hardiness-zone maps based on this same general zonation system have been developed for many parts of the world, including Australia (Dawson, 1991), China (Widrlechner, 1997a), Europe (Heinze and Schreiber, 1984), Japan (Hayashi, 1990), southern Africa (Pienaar, 1996), and Ukraine (Widrlechner et al., 2001). In various parts of the world, including the United States (DeGaetano and Shulman, 1990; Sunset, 2010; Vogel et al., 2005), alternative zonation systems that do

Table 1. Comparison of the updated and 1990 Plant Hardiness Zone Map $(\mathrm{PHZM})$ zone temperature ranges. The updated PHZM has full $5.6^{\circ} \mathrm{C}\left(10^{\circ} \mathrm{F}\right)$ zones, which are defined by the numbers $1-13$. These are separated into $2.8^{\circ} \mathrm{C}$ $\left(5^{\circ} \mathrm{F}\right)$ half zones, denoted by an a or $\mathrm{b}$.

\begin{tabular}{|c|c|c|c|}
\hline \multirow[b]{2}{*}{1990 zones } & \multirow[b]{2}{*}{ Updated zones } & \multicolumn{2}{|c|}{ Temperature range } \\
\hline & & ${ }^{\circ} \mathbf{C}$ & ${ }^{\circ} \mathbf{F}$ \\
\hline 1 & la & -51.1 to -48.3 & -60 to -55 \\
\hline 1 & $1 b$ & -48.3 to -45.6 & -55 to -50 \\
\hline $2 \mathrm{a}$ & $2 \mathrm{a}$ & -45.6 to -42.8 & -50 to -45 \\
\hline $2 b$ & $2 b$ & -42.8 to -40.0 & -45 to -40 \\
\hline $3 a$ & $3 a$ & -40.0 to -37.2 & -40 to -35 \\
\hline $3 b$ & $3 b$ & -37.2 to -34.4 & -35 to -30 \\
\hline $4 \mathrm{a}$ & $4 a$ & -34.4 to -31.7 & -30 to -25 \\
\hline $4 b$ & $4 b$ & -31.7 to -28.9 & -25 to -20 \\
\hline $5 a$ & $5 a$ & -28.9 to -26.1 & -20 to -15 \\
\hline $5 b$ & $5 b$ & -26.1 to -23.3 & -15 to -10 \\
\hline $6 a$ & $6 a$ & -23.3 to -20.6 & -10 to -5 \\
\hline $6 b$ & $6 b$ & -20.6 to -17.8 & -5 to 0 \\
\hline $7 \mathrm{a}$ & $7 a$ & -17.8 to -15.0 & 0 to 5 \\
\hline $7 \mathrm{~b}$ & $7 \mathrm{~b}$ & -15.0 to -12.2 & 5 to 10 \\
\hline $8 a$ & $8 \mathrm{a}$ & -12.2 to -9.4 & 10 to 15 \\
\hline $8 \mathrm{~b}$ & $8 \mathrm{~b}$ & -9.4 to -6.7 & 15 to 20 \\
\hline $9 \mathrm{a}$ & $9 a$ & -6.7 to -3.9 & 20 to 25 \\
\hline $9 \mathrm{~b}$ & $9 \mathrm{~b}$ & -3.9 to -1.1 & 25 to 30 \\
\hline $10 \mathrm{a}$ & $10 \mathrm{a}$ & -1.1 to 1.7 & 30 to 35 \\
\hline $10 \mathrm{~b}$ & $10 \mathrm{~b}$ & 1.7 to 4.4 & 35 to 40 \\
\hline 11 & $11 a$ & 4.4 to 7.2 & 40 to 45 \\
\hline 11 & $11 b$ & 7.2 to 10.0 & 45 to 50 \\
\hline- & $12 \mathrm{a}$ & 10.0 to 12.8 & 50 to 55 \\
\hline - & $12 b$ & 12.8 to 15.6 & 55 to 60 \\
\hline - & $13 a$ & 15.6 to 18.3 & 60 to 65 \\
\hline - & $13 b$ & 18.3 to 21.1 & 65 to 70 \\
\hline
\end{tabular}


not rely upon the PH statistic have been developed, but are generally not widely used in horticultural research, with the exception of the multivariate zonation system developed for Canada (Ouellet and Sherk, 1967), which is discussed below.

Preliminary efforts to update the 1990 PHZM in 2003 (Ellis, 2003) relied on outdated methodologies, leading to a draft map that was not adopted by USDA-ARS. In 2004, USDA-ARS initiated another effort to update the 1990 map, guided by modern standards of geostatistical analysis, accuracy, and resolution. Recently released products of these efforts are described in detail below. In addition, Daly et al. (2012) present a thorough discussion of the technical approaches taken to conduct this work.

HOW DO HARDINESS ZONES RELATE TO WINTERHARDINESS (OR LOW-TEMPERATURE SURVIVAL)? The ability of a plant to survive low temperatures depends on its genetically and environmentally controlled adaptations and its acclimation status. The utility of plant hardiness zone maps for measuring winter injury is a function of the correlation of the $\mathrm{PH}$ statistic to the frequency and severity of low-temperature events that damage aboveground plant parts over appropriate time intervals and space. In addition, it also is important to recognize and account for important modifying factors. These include environmental factors, such as levels of moisture, temperature, and light, and proper photoperiod regimens, that influence the full expression of the physiological and physical mechanisms that promote winter adaptation and those that hinder it, such as abrupt, wide temperature fluctuations and atypical dehardening events (Larcher, 2005; Levitt, 1980; Olsen et al., 2004; Raulston and Tripp, 1994).

Because of the dynamic nature of climate, the most appropriate use of plant hardiness zones is for the retroactive evaluation of plant performance within the same time span used to generate the map being applied. For example, Widrlechner et al. (1992) evaluated the performance of woody plants from Yugoslavia in the north-central United States between 1975 and 1989, which roughly corresponds to the period of record for the 1990 PHZM.
However, many horticulturists apply hardiness zones in a prospective manner, with an expectation that past climatic records can serve to forecast current and future plant performance, as related to low-temperature damage. Fortunately, for many parts of the United States, hardiness-zone boundaries have shifted relatively little, as evidenced by the 1960 (USDA, 1960), the 1990 (Cathey, 1990), and the recently updated maps, even though the zone boundaries are a function of the extreme weather events in the various years used to create the maps. Table 2 illustrates this relative stability among hardiness zones, as depicted in the three maps, for the 11 largest Metropolitan Statistical Areas in the United States (U.S. Census Bureau, 2003).

But the picture is somewhat different when differences in the $\mathrm{PH}$ statistic were evaluated solely for the two 15-year periods that encompass the 30-year interval (1976-2005) used to develop the most recent update (Daly et al., 2012). In that comparison, most of the conterminous United States was one half zone warmer in the period 1991-2005 than in 197690. Clearly, the world's climate is dynamic (Intergovernmental Panel on Climate Change, 2007), and zone boundaries may change in the future, based on modeled relationships between climate change and the occurrence of extreme low-temperature events (Diffenbaugh et al., 2005).

Sabuco (1989) created a modified plant hardiness zone map called Floradapt that incorporated snow cover, cloud cover, and wind speeds

Table 2. Comparison of plant hardiness zones mapped for the 11 largest Metropolitan Statistical Areas [MSAs (U.S. Census Bureau, 2003)] in the 1960, 1990, and recently revised Plant Hardiness Zone Maps.

\begin{tabular}{lccc}
\hline MSA & 1960 map & 1990 map & Revised map \\
\hline New York-Northern New Jersey-Long & $6-7$ & $6 \mathrm{~b}-7 \mathrm{a}$ & $7 \mathrm{a}-7 \mathrm{~b}$ \\
$\quad$ Island, NY-NJ-PA & & & \\
Los Angeles-Long Beach-Santa Ana, CA & $9-10$ & $9 \mathrm{~b}-10 \mathrm{~b}$ & $10 \mathrm{a}-1 \mathrm{la}$ \\
Chicago-Naperville-Joliet, IL-IN-WI & $5-6$ & $5 \mathrm{a}-5 \mathrm{~b}$ & $5 \mathrm{~b}-6 \mathrm{a}$ \\
Philadelphia-Camden-Wilmington, & 7 & $6 \mathrm{~b}-7 \mathrm{a}$ & $7 \mathrm{a}-7 \mathrm{~b}$ \\
$\quad$ PA-NJ-DE & & & \\
Dallas-Fort Worth-Arlington, TX & $7-8$ & $7 \mathrm{~b}-8 \mathrm{a}$ & $8 \mathrm{a}$ \\
Miami-Fort Lauderdale-Miami Beach, FL & 10 & $10 \mathrm{a}-10 \mathrm{~b}$ & $10 \mathrm{~b}$ \\
Washington-Arlington-Alexandria, & 7 & $6 \mathrm{~b}-7 \mathrm{a}$ & $7 \mathrm{a}-7 \mathrm{~b}$ \\
$\quad$ DC-VA-MD & 9 & $8 \mathrm{~b}-9 \mathrm{a}$ & $9 \mathrm{a}$ \\
Houston-Baytown-Sugar Land, TX & $5-6$ & $5 \mathrm{~b}-6 \mathrm{~b}$ & $5 \mathrm{~b}-6 \mathrm{~b}$ \\
Detroit-Warren-Livonia, MI & 6 & $6 \mathrm{a}$ & $6 \mathrm{a}-6 \mathrm{~b}$ \\
Boston-Cambridge-Quincy, MA-NH & 8 & $7 \mathrm{a}-7 \mathrm{~b}$ & $7 \mathrm{~b}-8 \mathrm{a}$ \\
\hline Atlanta-Sandy Springs-Marietta, GA & & &
\end{tabular}

as modifying factors to refine the $\mathrm{PH}$ ology has not been published. Few published studies systematically compare the utility of the $\mathrm{PH}$ statistic to other metrics related to winterhardiness. In Canada, where plant adaptation is typically strongly limited by winter severity, Ouellet and Sherk (1967) determined that geographic variation in plant adaptation was best explained by a multivariate approach involving a wide range of climatic metrics, with emphasis on the $\mathrm{PH}$ statistic but also including the frostfree period, summer rainfall, maximum temperature, snow cover and wind (Agriculture Canada, 1981). Their zonation system has been successfully applied in Canadian horticultural research (Richer et al., 2006; Richer-Leclerc et al., 1994, 1996; Rioux et al., 2000, 2004) and formed the basis of an updated map generated from modern climatic interpolation techniques (McKenney et al., 2001).

In the north-central United States, Widrlechner et al. (1992) compared the merits of the $\mathrm{PH}$ statistic to that of January mean temperatures and the proportion of years with temperatures below $-32^{\circ} \mathrm{C}\left(-25.6^{\circ} \mathrm{F}\right)$ in multiple-regression analyses designed to explain first-year and overall survival of 27 accessions of woody plants collected in Yugoslavia when grown at 14 sites across the region. They found no significant differences in the strengths of regression models involving these three different measures, suggesting that at least for European plants introduced into their target statistic, but the underlying method- 
region, they were equivalent in value as predictors of winterhardiness.

HOW DO HARDINESS ZONES RELATE TO GENERAL PLANT ADAPTATION? Clearly, the PH statistic is an important determinant (or a strong correlate of determinants) of the long-term survival and adaptation of perennial plants, but other climatic factors can also be very strong determinants (Skinner, 1962; Thompson et al., $2000)$. Two of the most widely studied of these determinants are warmseason heat and moisture balance.

Horticulturists have identified three primary variables related to warm-season heat and plant adaptation: night temperature (Deal and Raulston, 1989), annual days above $30^{\circ} \mathrm{C}\left(86^{\circ} \mathrm{F}\right)$ [American Horticultural Society (AHS) heat zones (Cathey, 1997)], and lack of sufficient heat units (Pigott, 1981; Pigott and Huntley, 1981). Notably, there are highly significant positive correlations between AHS heat zones (Table 3 ) and plant hardiness zones in the central and southeastern United States (Fig. IA and B). Strong correlations between these two important climatic determinants strengthen the apparent practical value of plant hardiness zones for predicting general plant adaptation. However, this relationship is absent in some parts of the western United States, such as central California, where heat zones can vary from 2 [ 1 to $7 \mathrm{~d}$ per year $\left.>30^{\circ} \mathrm{C}\left(86^{\circ} \mathrm{F}\right)\right]$ to 9 $\left[>120\right.$ to $150 \mathrm{~d}$ per year $>30{ }^{\circ} \mathrm{C}$ $\left.\left(86^{\circ} \mathrm{F}\right)\right]$ within plant hardiness zone $9\left[-1.1\right.$ to $-6.7^{\circ} \mathrm{C}\left(30\right.$ to $\left.\left.20^{\circ} \mathrm{F}\right)\right]$ (Fig. IC). Attempts to understand the highly variable climate of California on plant adaptation may have been

Table 3. American Horticultural Society Plant Heat Zones (adapted from Cathey, 1997).

\begin{tabular}{cc}
\hline Heat zone & $\begin{array}{r}\text { Avg number of days per } \\
\mathbf{y r}>\mathbf{8 6}{ }^{\circ} \mathbf{F}\left(\mathbf{3 0}{ }^{\circ} \mathbf{C}\right)\end{array}$ \\
\hline 1 & $<1$ \\
2 & $1-7$ \\
3 & $8-14$ \\
4 & $15-30$ \\
5 & $31-45$ \\
6 & $46-60$ \\
7 & $61-90$ \\
8 & $91-120$ \\
9 & $121-150$ \\
10 & $151-180$ \\
11 & $181-210$ \\
12 & $>210$ \\
\hline
\end{tabular}

the impetus for the broader, multivariate climatic zonation system developed by Sunset in California, first exclusively for the western United States, but expanded in 1997 to the eastern United States (Sunset, 1997) and, in 2001, to southwestern Canada, Alaska, and Hawaii (Brenzel, 2001).
Another important climatic factor, moisture balance (typically expressed as a ratio between precipitation and actual or potential evapotranspiration), has long been considered a key determinant in vegetation (plant-community) classification (Mather and Yoshioka, 1968; Stephenson, 1990, 1998). It has
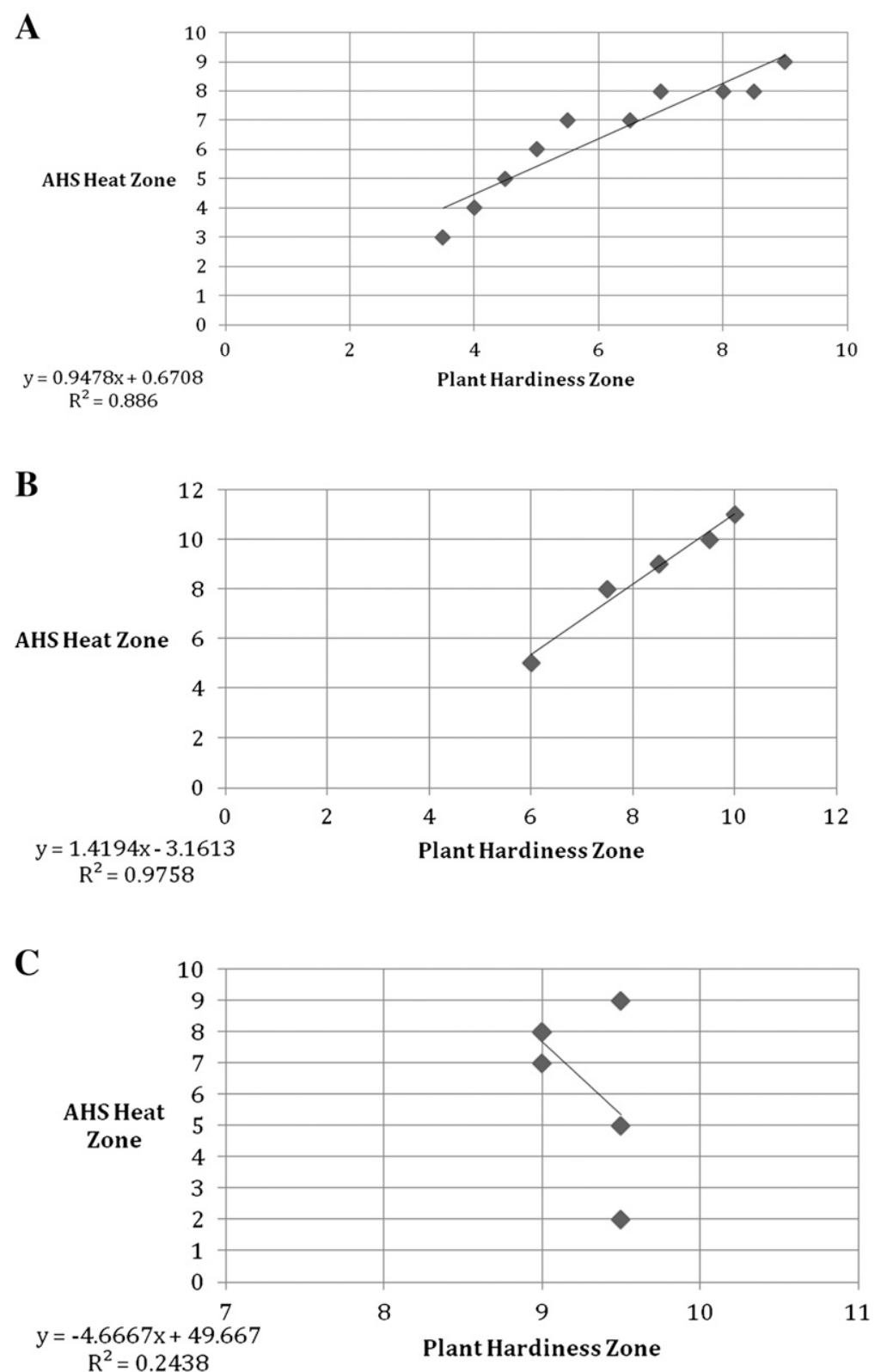

Fig. 1. Correlations between updated Plant Hardiness Zones (Table $\mathbf{1} ; \mathbf{x}$-axis) and American Horticultural Society (AHS) Heat Zones (Cathey, 1997) (Table 3; y-axis) for three transects. (A) Two-degree latitudinal intervals along a long. $95^{\circ} \mathrm{W}$ transect extending from lat. $30^{\circ} \mathrm{N}$ to lat. $48^{\circ} \mathrm{N}$ in the central United States ( $P$ value of regression line $<0.0001$ ); (B) two-degree latitudinal intervals along a long. $82^{\circ} \mathrm{W}$ transect extending from lat. $26^{\circ} 30^{\prime} \mathrm{N}$ to lat. $36^{\circ} 30^{\prime} \mathrm{N}$ in the southeastern United States ( $P$ value of regression line $<\mathbf{0 . 0 0 0 3 )}$; and $(C)$ fifteen-minute longitudinal intervals along a lat. $36^{\circ} 45 ” \mathrm{~N}$ transect extending from long. $120^{\circ} 30^{\prime} \mathrm{W}$ to long. $121^{\circ} \mathbf{4 5}$ "W in central California, where patterns of summer heat vary widely because of maritime influences but winter, low temperatures vary little ( $P$ value of regression line $<0.32$ ). 
also been used in conjunction with lowtemperature metrics for horticultural studies related to plant introduction in Ukraine (Kokhno and Kurdyuk, 1994) and the north-central United States (Widrlechner, 1994) and to the risk that cultivated plants can become naturalized (Widrlechner and Iles, 2002). Specific examples where the $\mathrm{PH}$ statistic was used jointly with moisture balance (and other environmental variables) include studies to identify climatic analogues as part of the planning and/or execution of plant explorations in China (Widrlechner, 1997b) and Ukraine (Widrlechner et al., 2001).

\section{The newly revised PHZM}

A newly updated, interactive PHZM for the United States and Puerto Rico has recently been produced (Fig. 2) and made available to the public via the Internet at http:// planthardiness.ars.usda.gov (USDA, 2012). Methods applied to produce this high-resolution map, its attributes, and key features that enable new applications for horticultural research and management, which were difficult or impossible to perform with the 1990 PHZM, are described in the following sections. A more detailed description of the new PHZM and its development are presented by Daly et al. (2012).

\section{How the map was created}

In 2004, the USDA-ARS assembled a technical review team (TRT), including representatives from the horticulture and nursery industries, public gardens, agro-meteorologists, climatologists, and plant scientists, and they developed technical guidelines and suggested ways to present the resulting information that maximize its value to researchers, the horticultural producers, gardeners, and governmental agencies. The TRT followed

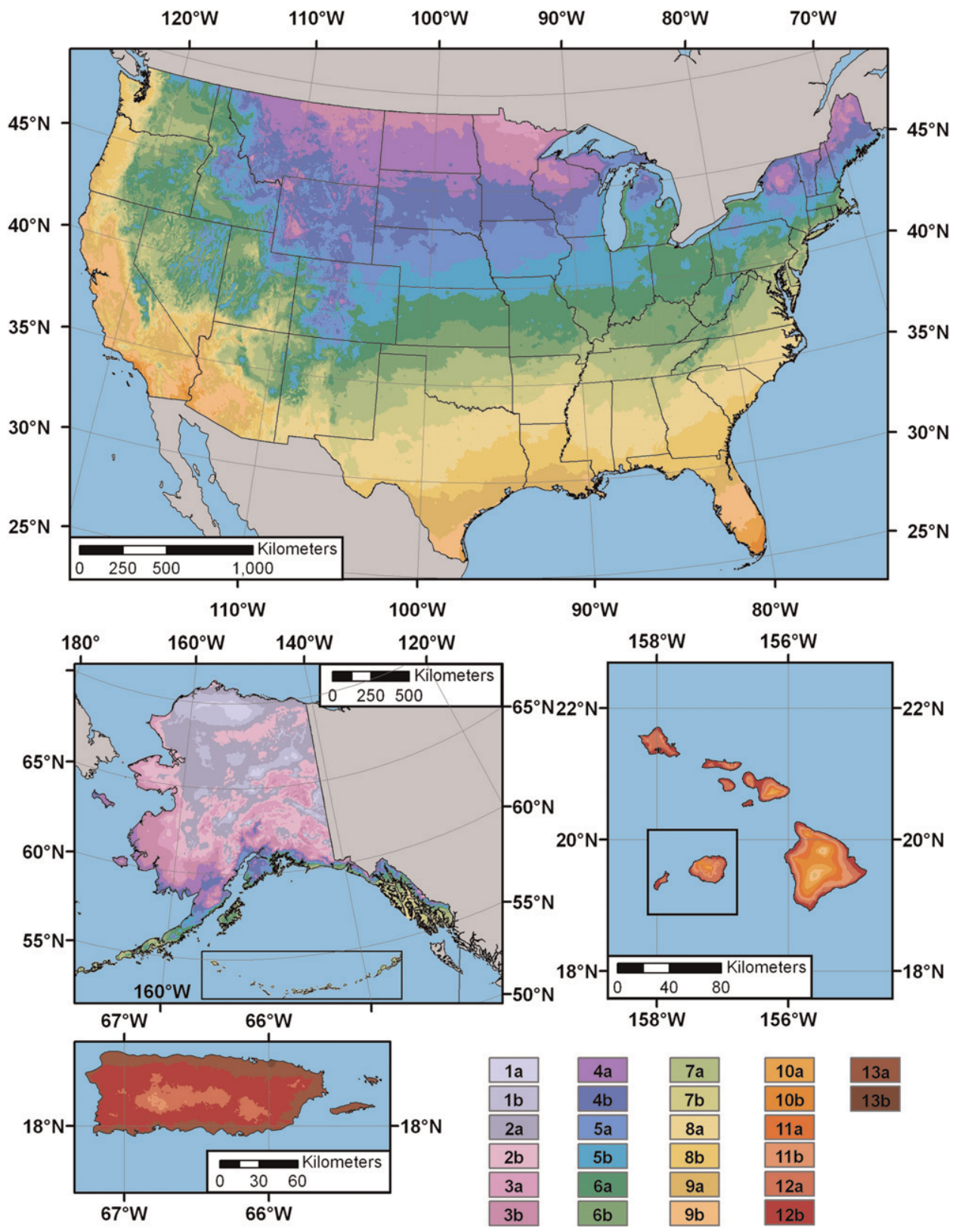

Fig. 2. PRISM 1976-2005 Plant Hardiness Zone Maps: (A) conterminous United States; (B) Alaska; (C) Hawaii; and (D) Puerto Rico. Zone shading key (color online) is given at the lower right. See Table 1 for temperature ranges of zones $(1 \mathrm{~km}=$ 0.6214 mile). (Figure appears in color online and on cover.) 
a flexible, multidisciplinary approach, incorporating input from horticultural industry and professional organizations, such as the AHS, American Nursery and Landscape Association, and American Public Gardens Association, as well as from within the USDA and the academic community.

The TRT recommended that a new PHZM incorporates the most recent and accurate meteorological data, applies the most advanced interpolation methods, and focuses only on plant cold hardiness, as measured by the $\mathrm{PH}$ statistic. Team members recognized that many other climatic datasets were available, potentially offering considerable insight into the geographic patterning of factors related to plant adaptation. Nonetheless, they decided to retain the existing system because of its widespread adoption, including the availability of estimates of winterhardiness based on the $\mathrm{PH}$ statistic for thousands of plants [three online examples include the NGA Plant Finder (National Gardening Association, 2010), Cornell University's Flower Growing Guides (Cornell University, 2006), and the UConn Plant Database (Brand, 2001)] and the assortment of compatible hardiness-zone maps available internationally. In addition, the TRT agreed to limit the new map's geographic focus to the United States and Puerto Rico since Canada had made significant progress with its alternative mapping scheme (McKenney et al., 2001) and, at the time, the density of Mexican weather stations with long-term data was unclear. In 2007, on the basis of its track record as a leader in climatic map development (e.g., Daly, 2006; Daly et al., 1994, 2008), Oregon State University's PRISM Climate Group was tasked by USDA-ARS with developing the updated PHZM.

The period 1976-2005 was chosen as the averaging interval for the new PHZM because it represented the most recent 30-year period for which there were reasonably complete data at the time the project began. A 30-year period was chosen instead of a shorter period because it is more stable statistically, samples recent climatological variation more completely, and depicts with higher fidelity the role that past winters have played on the survival of long-lived plants. In addition, the TRT conducted extensive reviews of draft maps and associated data and provided detailed feedback to the PRISM Climate Group. During the draft map review process, the 30-year period also emerged as the interval that best matched the expectations, perceptions, and experience of TRT reviewers.

Temperature data from 7983 stations were obtained for the United States and Puerto Rico, and adjacent regions in Canada and Mexico (to fill in gaps in coverage near these international borders). Stations located in mountainous areas were included in large numbers for the first time. These included 583 USDA Natural Resources Conservation Service SNOTEL (Snow Telemetry) stations, located at high elevations in the western United States. The data were carefully qualitycontrolled for outliers and other inconsistent values (methods are detailed in Daly et al., 2008).

The 1976-2005 PHZM was produced with the most recent version of parameter-elevation regressions on independent slopes model (PRISM), a well-known climate mapping technology that has generated official USDA 1961-90 digital climate grids and 1971-2000 updates (Daly, 2006; Daly et al., 1994, 2002, 2008). PRISM develops local regression functions (one for each grid cell on a map) between a predictor grid of an explanatory variable (most commonly elevation) and a climatic variable, for every grid cell. Data from surrounding stations, weighted by their geographic similarity to the grid cell being modeled, populate the regression function. PRISM accounts for the effects of elevation, terrain-induced air-mass blockage, coastal proximity, temperature inversions, and cold-air pooling on extreme minimum-temperature patterns (Daly et al., 2008). More information about PRISM can be obtained from PRISM Climate Group (2010).

Climatologically aided interpolation [CAI (Daly, 2006; Willmott and Robeson, 1995)] was used to interpolate the PHZM. Here, instead of using elevation as the predictor grid (independent variable in the PRISM local regression function), the CAI method involves using a previously interpolated grid that represents the long-term mean of a related climatological variable as the predictor. In this case, the best predictor for the CAI of the PH statistic was found to be the 1971-2000 mean monthly minimum temperature of the coldest month of the year, derived from the official PRISM climate datasets for the USDA (Daly et al., 2008). The PHZM was produced at high resolution $(800 \mathrm{~m}$ in the conterminous United States, $4 \mathrm{~km}$ in Alaska, and $400 \mathrm{~m}$ in Hawaii and Puerto Rico) and divided into thirteen $5.6^{\circ} \mathrm{C}\left(10^{\circ} \mathrm{F}\right)$ full zones and twenty-six $2.8^{\circ} \mathrm{C}\left(5^{\circ} \mathrm{F}\right)$ half zones (Table 1). Maps of the standard deviation of the 1976-2005 PH statistic were created with the same methods, and incorporated the same stations, as did the PHZM interpolation (Daly et al., 2012).

\section{General features of the updated PHZM}

The latitudinal delineation of zones in the central part of the conterminous United States is readily apparent, ranging from zone $3 \mathrm{a}$ in extreme northern Minnesota to zone 10a in extreme southeastern Texas (Fig. 2). Although the eastern United States has somewhat similar latitudinal patterns, they are modulated by elevational and coastal influences. For example, zone 6a extends southward along the Appalachian Mountains into northern Georgia, but also extends along the Atlantic coastline as far north as Maine. A combination of latitudinal and maritime influences (particularly noticeable along the Atlantic coast, see Fig. 2A) results in extremely mild zones that are essentially frost-free in southern Florida (zones $1 \mathrm{la}$ and $\mathrm{llb}$ ).

Zone patterns in the western United States exhibit only an indistinct latitudinal gradient; instead, they are dominated by relatively mild marine influences along the West Coast, elevational effects in the mountains, and cold-air pools in many interior valleys. The Cascade Range in the Pacific northwestern United States and the Sierra Nevada in California limit the eastward penetration of mild Pacific air, creating sharp zonal contrasts along their crests. The Rocky Mountains act as a barrier to outbreaks of frigid air from northern Canada, resulting in milder zones west of the Rockies than to the east. These infrequent arctic outbreaks when they do enter the western United States and Canada often have serious horticultural impacts (see Quamme et al., 2009). Topographic effects on the spatial distribution of the $\mathrm{PH}$ statistic 
are complex, due to competing effects of cooling with elevation and cold-air pooling in valleys. The coldest zones in the western United States are located not at the highest elevations, but rather in interior valleys where persistent cold-air pooling occurs (see Figs. 4 and 5 in Daly et al., 2008).

Not surprisingly, the coldest zones in the United States occur in Alaska (Fig. 2B). However, zones with winters as warm as those of southern Alabama occur along the Gulf of Alaska coastline and Aleutians. In southern Alaska, the Chugach Mountains present a formidable barrier between dominant coastal and interior air masses, creating gradients of up to ten half zones between the coastal strip and adjacent regions less than $100 \mathrm{~km}$ inland.

The zones with the warmest $\mathrm{PH}$ values are found in Hawaii and Puerto Rico (Fig. 2C and D). Again, elevation and coastal influence are the dominant factors controlling spatial distribution of zones. Hawaii encompasses a wide range of zones, from $9 \mathrm{a}$ on the summits of Mauna Loa and Mauna Kea to zone 13a in the mildest coastal locations. Puerto Rico, owing to its location in the relatively warm Caribbean Sea and southern latitude, has the warmest $\mathrm{PH}$ values of all the regions mapped. An extensive coastal strip of zone 13a delineates low-elevation areas moderated by nearby ocean temperatures. In the interior, temperatures cool with elevation. Interestingly, the coolest zone on the island ( $11 \mathrm{~b}$ ) occurs in an elevated, interior valley, where cold air pools frequently on winter nights, and in adjacent highlands.

Clearly, plant hardiness conditions vary over time, both within years and between them, and the magnitude of this temporal variability is not constant across the United States. A map of the standard deviation of the 1976-2005 PH statistic in the conterminous United States (Fig. 3) shows that variability is greatest $\left[>5^{\circ} \mathrm{C}\left(9^{\circ} \mathrm{F}\right)\right]$ in the intermountain region of the western United States and also in the southeast midwestern United States (Ohio River Valley). Generally, under the assumption that annual extreme minimum-temperature values are normally distributed over time, it is possible to estimate the frequency of extreme events that are one or more hardiness zones colder or warmer than the mapped zone for a given location, based on standard deviations. Table 4 presents data that relate standard deviations from Fig. 3 to the frequencies of such events, including those that are one half zone, one full zone, and two full zones beyond the mapped zone.

A $5{ }^{\circ} \mathrm{C}\left(9^{\circ} \mathrm{F}\right)$ standard deviation translates into about a $13 \%$ chance ( 1 year in 7.6 years) that, in any given year, the $\mathrm{PH}$ statistic could be at least two half zones colder than the mean, and another $\approx 13 \%$ chance that it could be at least two half zones warmer (Table 4). In a few locations in the intermountain west (Idaho, Montana, Oregon, Utah, and Washington), standard deviations exceeded $7^{\circ} \mathrm{C}$ $\left(12.6^{\circ} \mathrm{F}\right)$. These areas experienced such large annual fluctuations in the $\mathrm{PH}$ statistic that winter conditions for long-lived plants were likely much harsher than in other, less variable regions sharing that zone. At such high standard deviations, one might expect a winter that is two hardiness zones colder than the mapped zone to occur about every 18 years (Table 4 ). In contrast, the standard deviation is

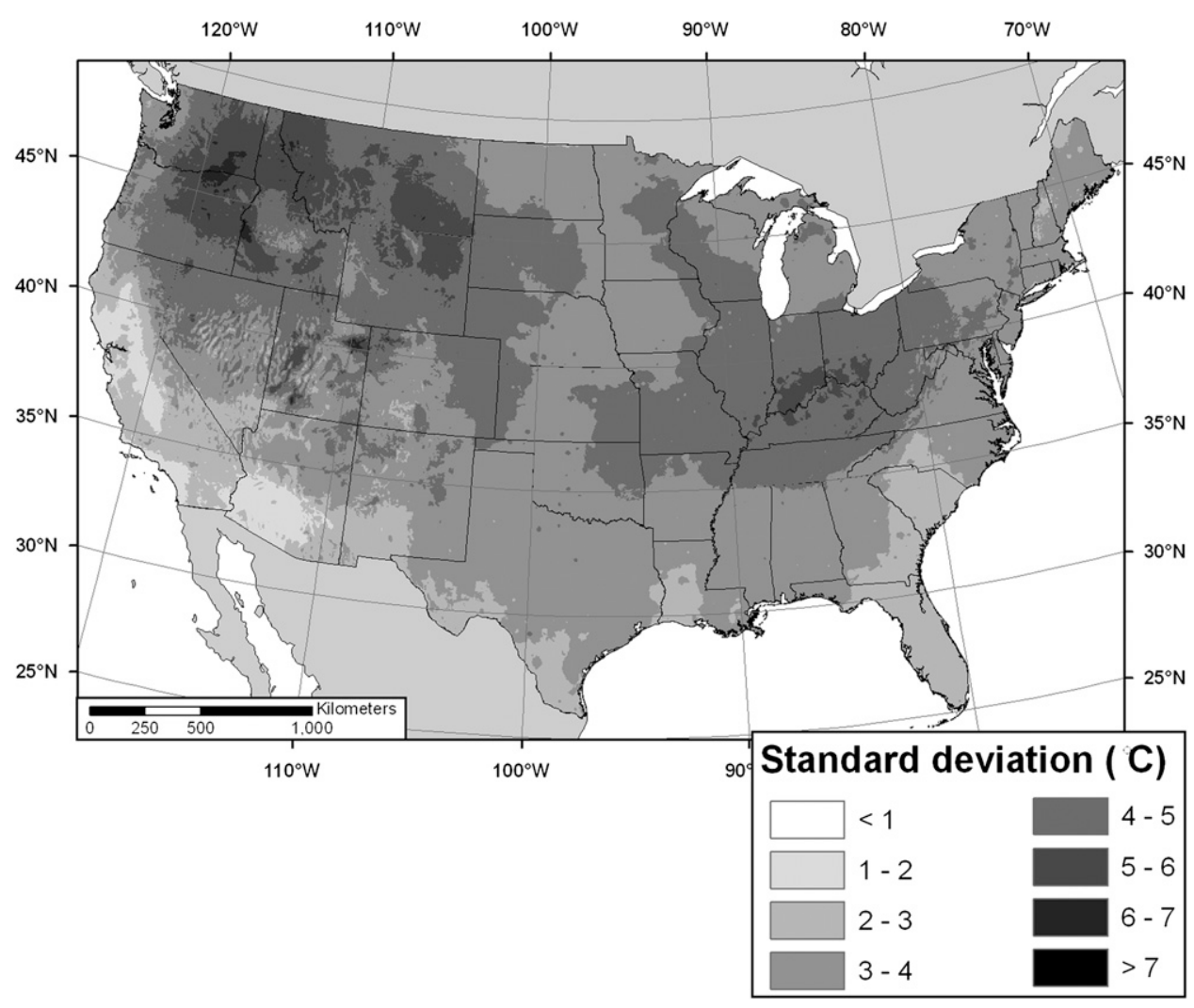

Fig. 3. PRISM 1976-2005 map of standard deviation of the plant hardiness statistic for the conterminous United States. Zone shading key is given at the lower right $\left(1^{\circ} \mathrm{C}=1.8^{\circ} \mathrm{F}, 1 \mathrm{~km}=0.6214 \mathrm{mile}\right)$. 
Table 4. Frequency of years with annual extreme minimum temperatures that are colder or warmer than the mapped plant hardiness zone for a given location, based on standard deviations (see Fig. 3) and an assumption of normally distributed temperature values over time.

\begin{tabular}{|c|c|c|c|}
\hline Standard deviation & $\begin{array}{c}\text { Frequency of years that } \\
\text { are one half hardiness zone } \\
{\left[2.8^{\circ} \mathrm{C}\left(5^{\circ} \mathrm{F}\right)\right] \text { colder or warmer }} \\
\text { than the mapped zone }\end{array}$ & $\begin{array}{c}\text { Frequency of years that } \\
\text { are one hardiness zone } \\
{\left[5.6^{\circ} \mathrm{C}\left(10^{\circ} \mathrm{F}\right)\right] \text { colder or }} \\
\text { warmer than the mapped zone }\end{array}$ & $\begin{array}{c}\text { Frequency of years that } \\
\text { are two hardiness zones } \\
{\left[11.1^{\circ} \mathrm{C}\left(20^{\circ} \mathrm{F}\right)\right] \text { colder or }} \\
\text { warmer than the mapped zone }\end{array}$ \\
\hline $2^{\circ} \mathrm{C}\left(3.6^{\circ} \mathrm{F}\right)$ & 1 year in 12.4 years & 1 year in 385 years & $<1$ year in 5000 years \\
\hline $3{ }^{\circ} \mathrm{C}\left(5.4^{\circ} \mathrm{F}\right)$ & 1 year in 5.7 years & 1 year in 32.3 years & 1 year in 5000 years \\
\hline $4^{\circ} \mathrm{C}\left(7.2^{\circ} \mathrm{F}\right)$ & 1 year in 4.1 years & 1 year in 12.4 years & 1 year in 385 years \\
\hline $6^{\circ} \mathrm{C}\left(10.8^{\circ} \mathrm{F}\right)$ & 1 year in 3.1 years & 1 year in 5.7 years & 1 year in 32.3 years \\
\hline $7^{\circ} \mathrm{C}\left(12.6^{\circ} \mathrm{F}\right)$ & 1 year in 2.9 years & 1 year in 4.7 years & 1 year in 18.2 years \\
\hline
\end{tabular}

lowest $\left[\leq 2^{\circ} \mathrm{C}\left(3.6^{\circ} \mathrm{F}\right)\right]$ in the Central Valley of California and the desert southwestern United States; there, it is unlikely that minimum-temperature conditions in any given year varied significantly from the mapped zone. In such areas, more than 300 years might transpire between winters that are one full hardiness zone colder than that mapped (Table 4).

\section{New features of the PHZM that enable special applications}

In the following section, we present three new features of the updated PHZM and describe some practical applications related primarily to horticultural production, marketing, and research.

FINE-RESOLUTION MAPPING AS A TOOL FOR SITE EVAluation. Cold injury is not a limiting factor in grape (Vitis spp.) production in most California growing regions, but it is critical in many other important grape production areas in the United States, such as the Pacific northwestern region, especially east of the Cascade Range. Compared with the 1990 PHZM, the updated map's fine resolution at $800 \mathrm{~m}$ for the conterminous United States combined with zooming ability permits a much more accurate assessment of the risk of winter injury across existing horticultural production areas (Fig. 4). In addition, this feature can be used as a preliminary decision-aid tool in site selection, for example, in new orchard and vineyard developments. This could be especially useful where industry expansion involves planting in relatively new areas, such as is currently occurring in the Pacific northwestern United States, where the booming wine industry requires a steady and reliable increase in grape supply.
As an example, the Walla Walla region in southeastern Washington and northeastern Oregon has been considered a premium wine region since the 1860s (Irvine and Clore, 1997). However, vineyard plantings there have been limited by comparison with other areas in the Pacific northwestern United States, with $<5 \%$ (about $650 \mathrm{ha}$ ) of Washington's wine grape acreage located there (Washington Wine Commission, 2010). A major reason for this restraint is the historical risk of recurring cold injury and uncertainty regarding potential vineyard sites that minimize such risk. Nonetheless, the 1990 PHZM mapped much of the Walla Walla Valley in a warmer hardiness zone (7a) than were the Columbia and Yakima Valleys (6b) farther to the west (Fig. 5A), which are established grape-growing regions and have traditionally experienced less severe winter damage. The updated map corrects that probable misclassification (Fig. 5C) and also permits tentative identification of broad mesoclimates with lower risk than are typical within the region. The new map also identifies a region in zone $7 \mathrm{~b}$ around Lewiston in western Idaho, northeast of Walla Walla (Fig. 5C), that was absent from the old map (Fig. 5A). Although this area was another successful early grape production site (Irvine and Clore, 1997), industry revival following its demise due to prohibition has only begun during the last 5 years. According to the new PHZM, low winter temperatures here would be expected to be less limiting than in many of Washington's established wine-grape-growing regions.

Most growers expect their newly established vineyard to remain productive for 30 years or more. The risk- assessment ability of the updated PHZM is further enhanced when used in conjunction with maps of the 30year standard deviation in the $\mathrm{PH}$ statistic (Fig. 3; Daly et al., 2012) and of elevation (US Geological Survey, 2006). Temperatures $<-25{ }^{\circ} \mathrm{C}$ $\left(-13{ }^{\circ} \mathrm{F}\right)$ kill most European wine grape (Vitis vinifera) cultivars even at their maximal level of midwinter cold hardiness (Davenport et al., 2008; Mills et al., 2006), which, at first glance, would permit successful grape cultivation down to about zone 6a. However, vineyards are typically not viable in regions where such killing freezes occur more frequently than every 8 to 10 years. The standard deviation map, in conjunction with Table 4, can help determine the likelihood of colder than average lowest temperatures occurring over longer time frames. These considerations suggest that winter survival is much more likely in zones $7 \mathrm{a}$ or warmer zones, with cold injury very unlikely in zones $8 \mathrm{a}$ and above. But even within zones $7 \mathrm{a}$ and $7 \mathrm{~b}$, standard deviations can vary considerably (e.g., Fig. 5); lower values are associated with lower risk (Table 4). Returning to the Walla Walla example, with the 6 to $7^{\circ} \mathrm{C}$ $\left(10.8\right.$ to $12.6^{\circ} \mathrm{F}$ ) standard deviation that prevails in the valley (zone $7 \mathrm{a}$ ), about one in five years can be expected to reach minimum temperatures that are characteristic for zone 6a (Table 4), and hence just marginal to avoid a killing freeze. By overlaying the PHZM with the standard deviation and elevation maps, one can identify several mesoclimates in the foothills of the Blue Mountains in zone 7a with about $1{ }^{\circ} \mathrm{C}\left(1.8^{\circ} \mathrm{F}\right)$ smaller standard deviations than those which characterize sites further down in the valley to the west and northwest (Fig. 5E). 


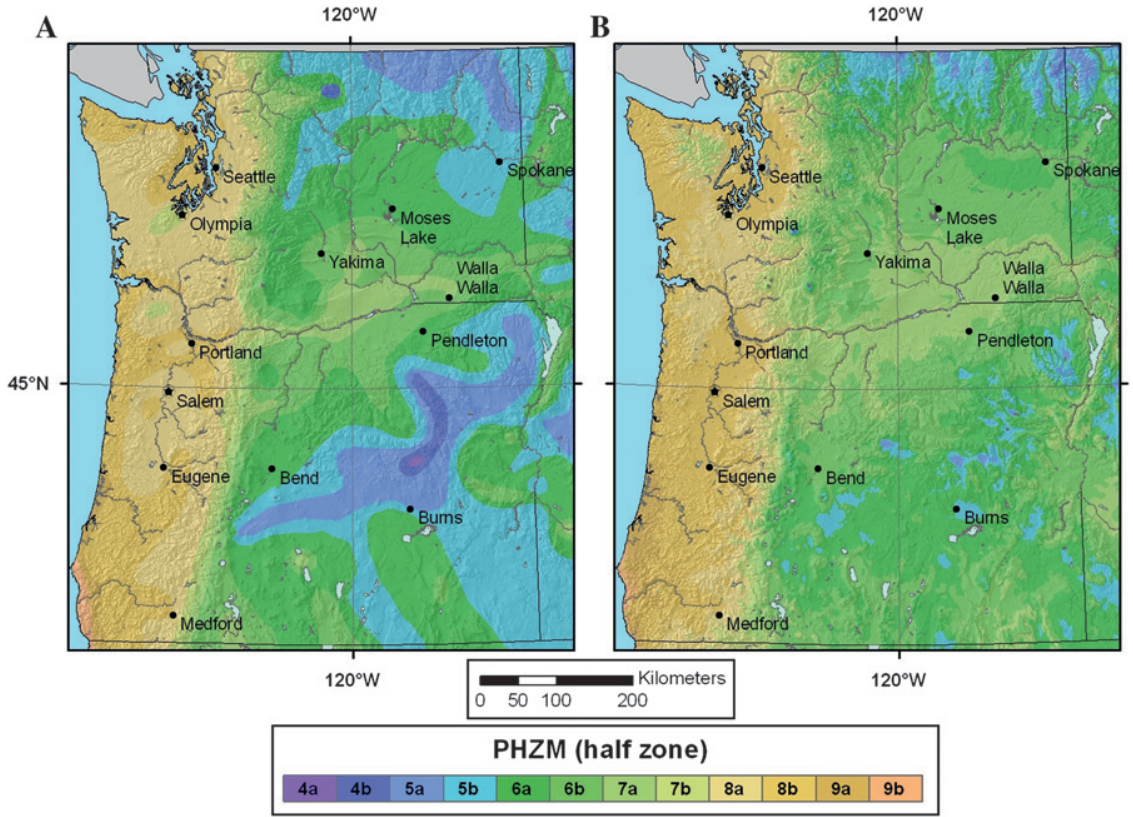

Fig. 4. Comparison of the 1990 Plant Hardiness Zone Map [PHZM (A)] and the updated version (B) for Oregon and Washington. Increased detail in the updated version was achieved primarily by applying interpolation methods that reproduce topographically based climatic patterns. The original color scheme of the 1990 map has been changed to match that of the updated version to allow a more direct visual comparison of the two maps $(1 \mathrm{~km}=0.6214 \mathrm{mile})$.
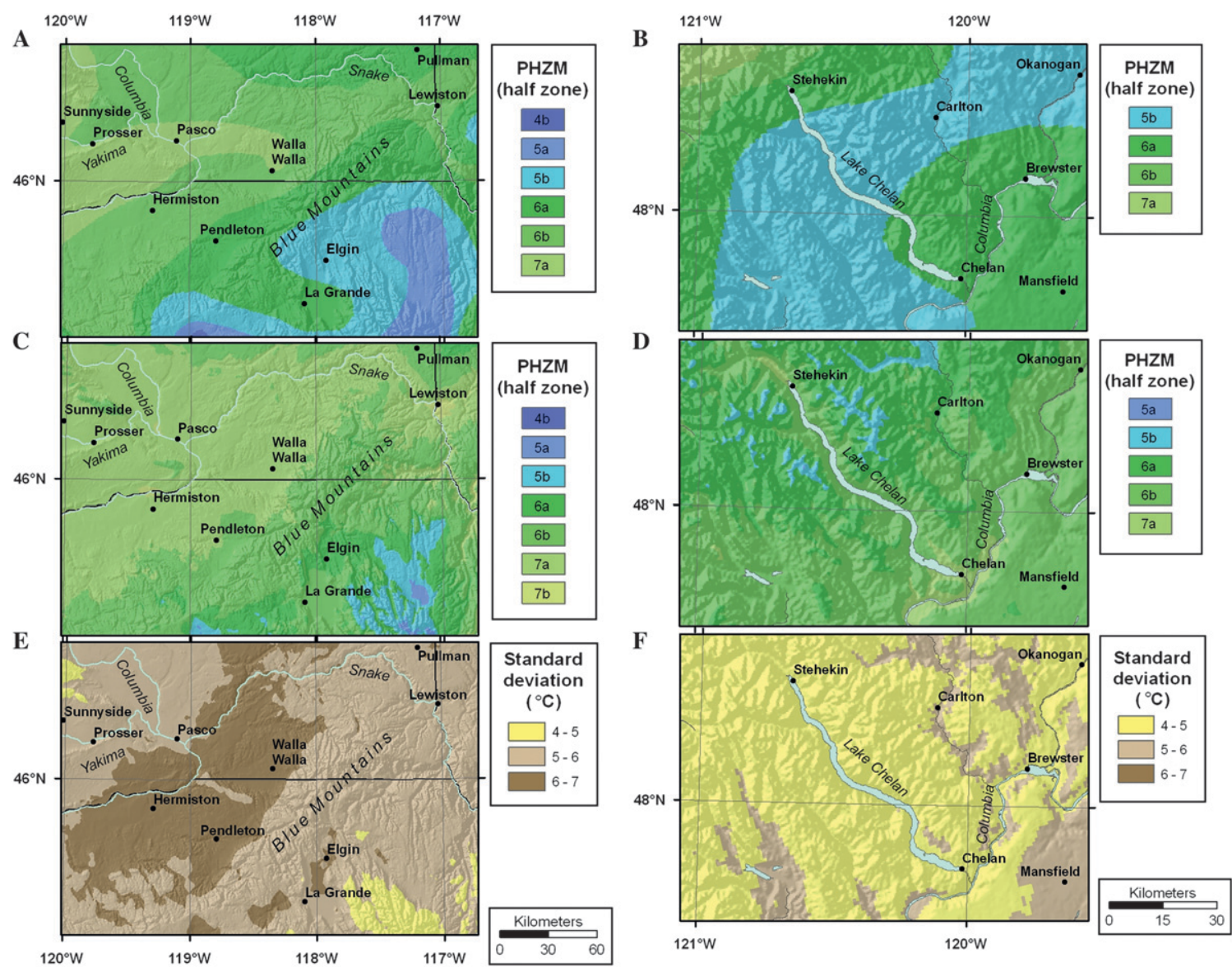

Fig. 5. Comparison of the 1990 Plant Hardiness Zone Map [PHZM (A and B)] the updated version (C and D), and the standard deviation (E and F) for the tri-state corner of southeastern Washington, northeastern Oregon, and western Idaho (left side), and the Lake Chelan region of central Washington (right side). The original color scheme of the 1990 map has been changed to match that of the updated version to allow a more direct visual comparison of the two maps $\left(1 \mathrm{~km}=0.6214 \mathrm{mile}, 1^{\circ} \mathrm{C}=1.8{ }^{\circ} \mathrm{F}\right)$. 
Because this decreases the frequency of zone-6a temperatures to 1 year in 6 to 8 years (Table 4 ), these sites can be considered less risky for grape production.

The Lake Chelan region of central Washington is another example where the 1990 PHZM apparently failed to account for local variation by placing the region on the border between zones $6 \mathrm{a}$ and $5 \mathrm{~b}$ (Fig. 5B). Although these zones are too risky for the long-term survival of European wine grapes, vineyard development has recently been increasing near Chelan (Washington Wine Commission, 2010). In support of this development, the updated PHZM identifies mesoclimates near Lake Chelan ranging from zone $6 \mathrm{~b}$ to $7 \mathrm{a}$ with the warmer areas around the town of Chelan (Fig. 5D) and with standard deviations equivalent to or lower than those of the Yakima Valley to the south and considerably lower than those found in the Walla Walla Valley (Fig. 5F). For example, the 4 to $5{ }^{\circ} \mathrm{C}(7.2$ to $9{ }^{\circ} \mathrm{F}$ ) standard deviation near Chelan (zone 7a) translates into 1 year in 8 to 12 years likely to experience temperatures typical of zone 6a (Table 4), which would pose only a minimal risk from killing freezes for most grape cultivars.

Use of The PH-statistic Data LAYER IN CONJUNCTION WITH OTHER CLIMATIC DATA FOR PLANT-ADAPTATION ANALYSES. In addition to the new PHZM produced from the highresolution $\mathrm{PH}$-statistic grid, the grid itself is also a valuable tool for horticulture. It can be combined with other high-resolution geographic datasets for a broad range of geospatial analyses. For example, Widrlechner et al. (1992) published a regression equation for predicting the survival of Yugoslavian woody plants in the north-central United States in terms of the PH statistic and moisture balance, $I_{\mathrm{m}}$. The regression equation is $S_{\mathrm{O}}=0.0309$ $\mathrm{PH}+0.0048 I_{\mathrm{m}}+1.2671$, where $S_{\mathrm{O}}$ is the overall proportion of plants surviving after 10 years, and $I_{\mathrm{m}}$ is calculated following Mather and Yoshioka (1968): $I_{\mathrm{m}}=[($ annual mean precipitation/potential evapotranspiration) -1$]$.

This regression equation emerged from analyses of the results of a 10-year, multisite evaluation of a broad range of trees and shrubs introduced from the former nation of Yugoslavia during the 1970s, as part of the NC7 Regional Ornamental Plant Trials (Widrlechner, 2004). At the time this study was published, no high-resolution datasets for either $\mathrm{PH}$ or $I_{\mathrm{m}}$ were publicly available, so the equation needed to be calculated from historical weather data, which were limited to specific weather stations. With the publication of a moisture-balance map for the north-central United States (Widrlechner, 1999), information from the 1990 PHZM could then be combined with that from the moisture-balance map to generate crude predictions of plant survival based on the regression equation.

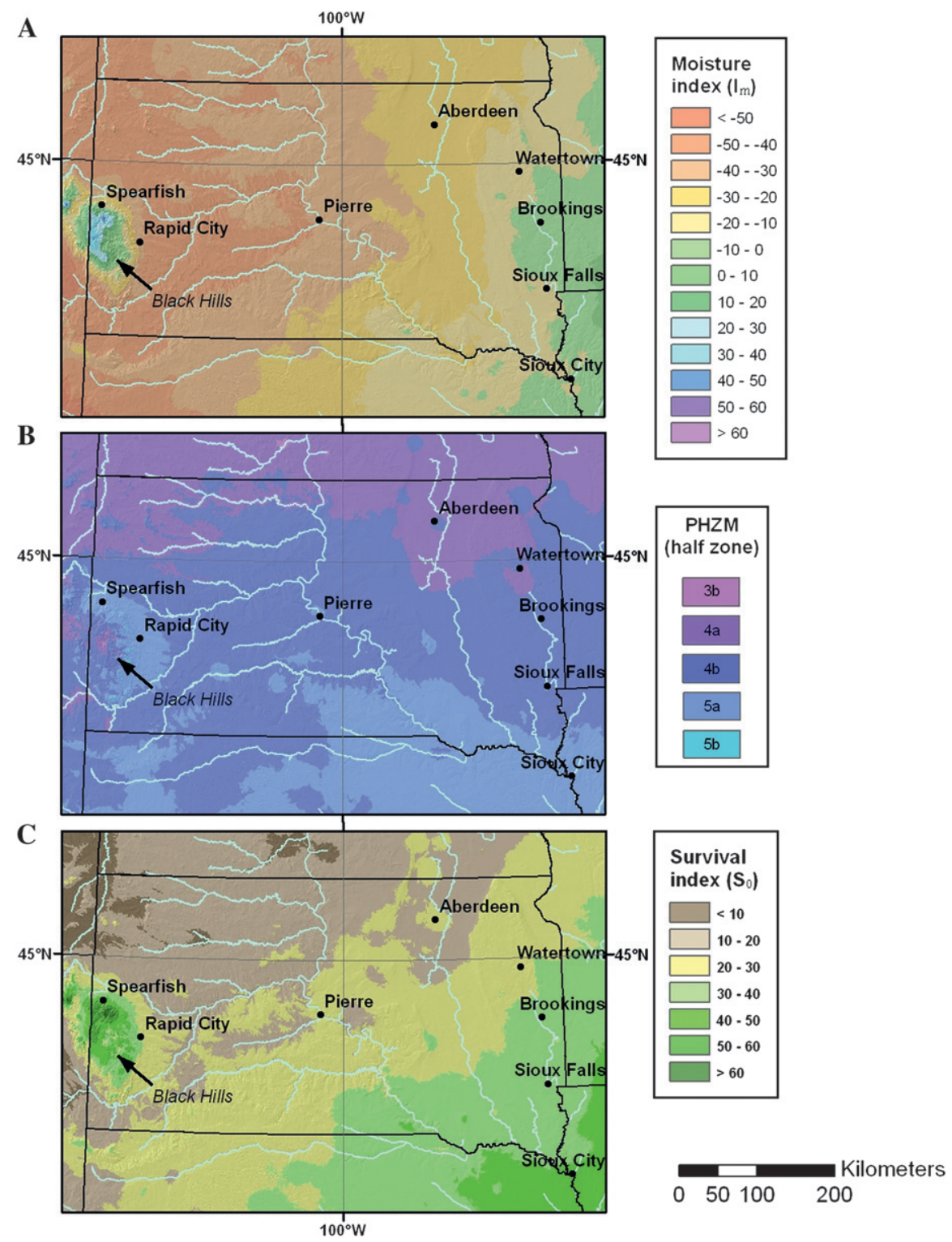

Fig. 6. South Dakota maps of the spatial distribution of $(\mathrm{A})$ moisture index $\left(I_{\mathrm{m}}\right)$; (B) updated Plant Hardiness Zone Map (PHZM); and (C) 10-year survival rate $\left(S_{0}\right)$ of woody plants introduced from Yugoslavia to the north-central United States, derived from the regression equation of Widrlechner et al. $(1992)(1 \mathrm{~km}=0.6214 \mathrm{mile})$. 
We selected South Dakota as an example to illustrate such a map for two reasons: first, because there were long-term trial sites that reported data from four of its neighboring states, but none in South Dakota. Thus, this information would fill a gap, enabling the selection of new trial sites for woodyplant evaluation in South Dakota. The second reason was because South Dakota has an unusual topographic and vegetation feature (the Black Hills) unlike any of the other states in the north-central region.

Three key aspects of woodyplant adaptation can be gleaned from Fig. 6C. First, a general southeast to northwest gradient in predicted percentages of plant survival can be observed, from about $40 \%$ survival in the extreme southeast corner of South Dakota to less than $10 \%$ in the northwest. That gradient conforms well to expectations based on data collected in surrounding states, where $S_{O}$ values varied from $3 \%$ in Burleigh County, $\mathrm{ND}$, to $48 \%$ in Carver County, MN, (Widrlechner et al., 1992). Second, the more local effect of cold-air drainage and pooling, common in certain river valleys, is readily apparent. In South Dakota, cold-air drainage influences plant survival most notably between Pierre and Rapid City, along the Bad and Cheyenne Rivers, where survival was estimated to be $<20 \%$ (Fig. 6B). Third, the Black Hills, a large "island" of mountainous, forested vegetation has a substantial influence on woodyplant survival. Its native vegetation is classified by Küchler (1964) as Black Hills Pine Forest, which is surrounded by grasslands (Campbell, 1997). $S_{O}$ survival values $>30 \%$ in western South Dakota (Fig. 6C) conform closely to the boundaries of Küchler's (1964) Black Hills Pine Forest. Notably, the model's highest predicted survival rates (about 60\%) also occur in the Black Hills, near Spearfish.

Although extensive woody vegetation in the Black Hills helps validate the model's results, we do have some reservations about the model's accuracy in this particular region. The model might locally overestimate survival because the Black Hills have two "special" climatic characteristics detrimental to woody-plant adaptation, which are unlike the remainder of the north-central United States, where the model was developed (and unlike much of the former nation of Yugoslavia).
These are an abbreviated growing season, with freezes possible in any month, and rapid, strong fluctuations in winter temperatures (National Oceanic and Atmospheric Administration, 1980), which, when they occur on both sides of the freezing point, can initiate drastic dehardening and cause winter injury. These fluctuations, produced by changes in cold-air drainage and dynamic chinook winds, are among the most extreme in North America. Burt (2004) provided details of the most extreme example, which was documented in Jan. 1943 in Spearfish and Rapid City. One or more long-term evaluation sites should be established within the Black Hills to incorporate this unusual climatic region into the NC7 Regional Ornamental Plant Trials and begin testing hypotheses about the climatic determinants of woodyplant adaptation.

The ZIP CODE FInder. The updated PHZM enables users to search for hardiness zones of specific sites by five-digit zip code. This feature has been developed in two forms, a freely available single-query tool on the website and a large-scale, batch process tool for commercial applications. Such tools to facilitate zip code-based website searches were first developed in the 1990s. Buyukkokten et al. (1999) were among the first to describe the concept of geographic extraction utilities, including a zip code finder, and to propose ways that these tools could improve data mining and increase the overall value of websites.

The PHZM zip code tools generate a hardiness-zone value based on the geographic center for each fivedigit zip code region in the United States. They were developed in response to the many requests received by USDA-ARS for a database that links zip codes to plant hardiness zones. The bulk of these requests fall into three categories:

1) Requests from governmental agencies. For example, the USDA Risk Management Agency (RMA) relates plant hardiness zones to specific locations when it sets standards for crop insurance for horticultural and nursery crops based on the use of crop protection, such as greenhouses or rowcovers, and in the development of the "Eligible Plant List and Plant Price Schedules" (USDA, 2010). RMA requested a searchable, automated connection between plant hardiness zones and zip codes. State and local natural resource conservation agencies also consult plant hardiness zones to craft guidelines for recommended trees and landscape plants for specific jurisdictions. Their recommendations can be more quickly and accurately developed by entering a location's zip code, confirming its zone, and relating the zones to published information about plant adaptation.

2) Requests from nurseries and other firms that widely distribute plants. Many nurseries that fulfill retail and wholesale orders for plants over large geographic areas, as well as mass retailers with national distribution, such as Home Depot, have also requested a zip code finder. It allows them to refine the timing of plant shipments by location based on delivery zip code, so plants are delivered at an optimal time for a nursery's customers, or for direct sale, in the case of mass retailers. Mass retailers can also apply a zip code finder to develop targeted lists of plants for sale that are more likely to survive local winter conditions near specific retail outlets.

3) Requests from the broader commercial sector. Beyond the "green industry," other firms also market products based on seasonal temperature considerations. They have expressed interest in zip code-based tools to develop more precise criteria for deciding when to begin marketing or otherwise increase activity by location. For example, a national termite-control firm has requested a way to integrate zip codes and plant hardiness zones to predict when termites and other insect pests may become active.

\section{Concluding remarks}

The development and public release of the updated PHZM will advance our understanding of landscape-plant adaptation and plant distribution through its presentation of accurate minimum-temperature data at a fine scale via a user-friendly interface readily accessible to researcher and gardener alike. We expect that it will be rapidly adopted as a research dataset in GIS and spatial analyses and will contribute to more effective planting recommendations, shipping management, and horticultural production.

A challenge for developing more refined hardiness zonation is how best 
to apply GIS tools and sophisticated interpolation techniques to the creation of zone maps that incorporate and weight appropriately all the key climatic factors influencing the adaptation of a wide spectrum of perennial plants. This is not a trivial challenge because these weightings will likely vary significantly by region and perhaps also by plant life forms. But as the body of research on relationships among climatic factors and patterns of plant adaptation grows, opportunities will undoubtedly arise for the creation and refinement of the next generation of plant hardiness zone maps.

We are excited about the research "dreams" that may now become attainable given the development and release of this new high-resolution PHZM based on modern interpolation techniques. And we look forward to collaborating with the horticultural research community to create the next generation of maps for the United States.

\section{Literature cited}

Agriculture Canada. 1981. Map of plant hardiness zones in Canada. Revised 1981. Land Resource Res. Inst. and Ottawa Res. Sta. Publ. 5003.

Bachtell, K.R. and T.L. Green. 1985. Two winters with record cold: Why was one a killer and the other not so bad? Amer. Nurseryman 162(2):53-61.

Brand, M.H. 2001. UConn plant database. Univ. of Connecticut, Storrs. 6 Aug. 2010. $<$ http://www.hort.uconn.edu/plants>.

Brenzel, K.N. 2001. The West's climate zones, p. 27-63. In: Sunset western garden book, new century ed. Sunset Publ., Menlo Park, CA.

Burt, C.C. 2004. Extreme weather: A guide and record book. Norton, New York.

Buyukkokten, O., J. Cho, H. GarciaMolina, L. Gravano, and N. Shivakumar. 1999. Exploiting geographical location information of web pages, p. 91-96. In: S. Cluet and T. Milo (eds.). Proc. of a workshop on the web and databases (WebDB'99) at ACM SIGMOD'99, Philadelphia, PA, 3-4 June 1999.

Campbell, R. 1997. South Dakota vegetation terms on maps. Augustana College, Sioux Falls, SD. 7 May 2010. <http:// www.augie.edu/dept/biology/tieszen/ rcampbell/SDvegmaps.html>.

Cathey, H.M. 1990. USDA plant hardiness zone map. USDA Misc. Publ. 1475 .
Cathey, H.M. 1997. Announcing the AHS plant heat-zone map. Amer. Gardener 76(5):30-37.

Cathey, H.M. and J. Heriteau. 1990. Mapping it out. Amer. Nurseryman 171(5):55-59, 61-63.

Cornell University. 2006. Flower growing guides. 22 Apr. 2010. <http:// www.hort.cornell.edu/gardening/ homegardening/sceneel39.html>.

Daly, C. 2006. Guidelines for assessing the suitability of spatial climate data sets. Int. J. Climatol. 26:707-721

Daly, C., W.P. Gibson, G.H. Taylor, G.L. Johnson, and P. Pasteris. 2002. A knowledge-based approach to the statistical mapping of climate. Clim. Res. 22:99-113.

Daly, C., M. Halbleib, J.I. Smith, W.P. Gibson, M.K. Doggett, G.H. Taylor, J. Curtis, and P.A. Pasteris. 2008. Physiographically-sensitive mapping of temperature and precipitation across the conterminous United States. Intl. J. Climatol. 28:2031-2064.

Daly, C., R.P. Neilson, and D.L. Phillips. 1994. A statistical-topographic model for mapping climatological precipitation over mountainous terrain. J. Appl. Meteorol. 33:140-158.

Daly, C., M.P. Widrlechner, M.D. Halbleib, and J.I. Smith. 2012. Development of a new USDA plant hardiness zone map for the United States. J. Appl. Meteorol. Climatol. 51:242-264.

Davenport, J.R., M. Keller, and L.J. Mills. 2008. How cold can you go? Frost and winter protection for grape. HortScience 43:1966-1969.

Dawson, I. 1991. Plant hardiness zones for Australia. Austral. Hort. 90(8):37-39.

Deal, D.L. and J.C. Raulston. 1989. Plant high night temperature tolerance zones describing and predicting summer night temperature patterns and the southern limits of plant adaptation. Agr. For. Meteorol. 46:211-226.

DeGaetano, A.T. and M.D. Shulman. 1990. A climatic classification of plant hardiness in the United States and Canada. Agr. For. Meteorol. 51:333-351.

Diffenbaugh, N.S., J.S. Pal, R.J. Trapp, and F. Giorgi. 2005. Fine-scale processes regulate the response of extreme events to global climate change. Proc. Natl. Acad. Sci. USA 102:15774-15778.

Ellis, D.J. 2003. The USDA plant hardiness zone map, 2003 edition. Amer. Gardener 82(3):30-35.

Gu, L., P.J. Hanson, W. Mac Post, D.P. Kaiser, B. Yang, R. Nemani, S.G. Pallardy, and T. Meyers. 2008. The 2007 eastern US spring freeze: Increased cold damage in a warming world? Bioscience 58:253-262.

Hayashi, Y. 1990. Jumoku ato bukku. Abokkusha, Kamakura-shi, Japan.

Heinze, W. and D. Schreiber. 1984. Eine neue Kartierung der Winterhärtezonen für Gehölze in Europa. Mitteilungen der Deutschen Dendrologischen Gesellschaft 75:11-56.

Intergovernmental Panel on Climate Change. 2007. Clim. Change 2007. Synthesis report. Intergovernmental Panel on Climate Change, Geneva, Switzerland.

Irvine, R. and W.J. Clore. 1997. The wine project. Washington state's winemaking history. Sketch Publications, Vashon, WA.

Kalcsits, L., S. Silim, and K. Tanino. 2009. The influence of temperature on dormancy induction and plant survival in woody plants, p. 108-118. In: L.V. Gusta, M.E. Wisniewski, and K.K. Tanino (eds.). Plant cold hardiness: From the laboratory to the field. CAB International, Wallingford, UK.

Kincer, J.B. 1928. Atlas of American agriculture. Climate. Temperature, sunshine, and wind. U.S. Government Printing Office, Washington, DC.

Kokhno, N.A. and A.M. Kurdyuk. 1994. Teoreticheskie osnovy i opyt introduktsii drevesnykh rastenii v Ukraine. Naukova Dumka, Kiev, Ukraine.

Küchler, A.W. 1964. Potential natural vegetation of the conterminous United States. (Map with manual). Amer. Geographical Soc., New York.

Larcher, W. 2005. Climatic constraints drive the evolution of low temperature resistance in woody plants. J. Agr. Meteorol. 61:189-202.

Levitt, J. 1980. Responses of plants to environmental stresses. Vol. 1. Chilling, freezing, and high temperature stresses. Academic Press, New York.

Litzow, M. and H. Pellett. 1980. Relationship of rest to dehardening in redosier dogwood. HortScience 15:92-93.

Mather, J.R. and G.A. Yoshioka. 1968. The role of climate in the distribution of vegetation. Ann. Assn. Amer. Geographers 58:29-41.

McKenney, D.W., M.F. Hutchinson, J.L. Kesteven, and L.A. Venier. 2001. Canada's plant hardiness zones revisited using modern climate interpolation techniques. Can. J. Plant Sci. 81:129-143.

McNamara, S. and H. Pellett. 1993. Flower bud hardiness of forsythia cultivars. J. Environ. Hort. 11:35-38. 
McNamara, S., H. Pellett, M. Florkowska, and O. Lindstom, Jr. 2002. Comparison of the cold hardiness of landscape tree and shrub cultivars growing at two disparate geographic locations. J. Environ. Hort. 20: 77-81.

Mills, L.J., J.C. Ferguson, and M. Keller. 2006. Cold hardiness evaluation of grapevine buds and cane tissues. Amer. J. Enol. Viticult. 57:194-200.

National Gardening Association. 2010. NGA plant finder. 22 Apr. 2010. <http://www.garden.org/plantfinder>.

National Oceanic and Atmospheric Administration. 1980. Climatography of the United States No. 60. Climate of South Dakota, p. 688-703. In: Climates of the states, 2nd ed., vol. 2. Gale Research, Detroit, MI.

Olsen, J.E., J.B. Jensen, J.A. Mölmann, A. Ernstsen, and O. Junttila. 2004. Photoperiodic regulation of apical growth cessation in northern tree species: The role of phytochrome and gibberellins. J. Crop Improv. 10(1/2):77-112.

Ouellet, C.E. and L.C. Sherk. 1967. Woody ornamental plant zonation, II: Suitability indices of localities. Can. J. Plant Sci. 47:339-349.

Pienaar, K. 1996. The ultimate book of trees and shrubs for southern African gardeners. Southern Book Publishers, Halfway House, South Africa.

Pigott, C.D. 1981. Nature of seed sterility and natural regeneration of Tilia cordata near its northern limit in Finland. Ann. Bot. Fenn. 18:255-263.

Pigott, C.D. and J.P. Huntley. 1981. Factors controlling the distribution of Tilia cordata at the northern limit of its geographical range. III. Nature and cause of seed sterility. New Phytol. 87:817-839.

PRISM Climate Group. 2010. PRISM climate group. 31 Aug. 2010. <http:// prism.oregonstate.edu/about_us.phtml $>$.

Quamme, H.A., A.J. Cannon, D. Neilsen, J.M. Caprio, and W.G. Taylor. 2009. The occurrence of winter-freeze events in fruit crops grown in the Okanagan Valley and the potential impact of climate change, $p$. 190-197. In: L.V. Gusta, M.E. Wisniewski, and K.K. Tanino (eds.). Plant cold hardiness: From the laboratory to the field. $\mathrm{CAB}$ International, Wallingford, UK.

Raulston, J.C. and K.E. Tripp. 1994. Exploring the complexities of plant hardiness. Arnoldia 54(3):22-31.

Rehder, A. 1927. Manual of cultivated trees and shrubs. Macmillan, New York.

Richer, C., J.A. Rioux, and M.P. Lamy. 2006. Évaluation de la tolérance de neuf rhododendrons aux diverses conditions climatiques du nord-est canadien. Can. J. Plant Sci. 86:787-798.

Richer-Leclerc, C., J.A. Rioux, J. Côté, and R. Drapeau. 1996. Caractérisation du potentiel de rusticité de sept arbustes ornementaux en fonction de l'intensité des dommages hivernaux. Can. J. Plant Sci. 76:499-506.

Richer-Leclerc, C., J.A. Rioux, D. Lapointe, J. Côté, L. Guillemette, R. Drapeau, M. Auger, and M. Fortin. 1994. Évaluation de la rusticité et de la croissance d'arbustes ornementaux à feuillage caduc. Can. J. Plant Sci. 74: 615-622.

Rioux, J.A., P. Marquis, C. Richer, and M.P. Lamy. 2000. Évaluation de la tolérance du Thuja occidentalis L. et de huit de ses cultivars aux conditions climatiques du nord-est canadien. Can. J. Plant Sci. 80:631-637.

Rioux, J.A., C. Richer, and M.P. Lamy. 2004. Evaluation de la tolérance de onze genévriers (Juniperus sp.) aux diverses conditions climatiques du nord-est canadien. Can. J. Plant Sci. 84:1135-1153.

Sabuco, J.J. 1989. Floradapt. Flora's winter adaptability (a plant hardiness zone map). White Oak Group, Chicago Heights, IL.

Scheiber, S.M., C.D. Robacker, and O.M. Lindstrom. 2002. Stem and leaf hardiness of 12 Abelia taxa. J. Environ. Hort. 20: 195-200.

Schrader, J.A. and W.R. Graves. 2003 Phenology and depth of cold acclimation in the three subspecies of Alnus maritima. J. Amer. Soc. Hort. Sci. 128: 330-336.

Skinner, H.T. 1962. The geographic charting of plant climatic adaptability, p. 485-491. In: J-C. Garnaud (ed.). Advances in horticultural science and their applications. Vol. 3. Proc. of the 15th Intl. Hort. Congr., Nice, France, 1958. Macmillan, New York.

Stephenson, N.L. 1990. Climatic control of vegetation distribution: The role of the water balance. Amer. Nat. 135:649670 .

Stephenson, N.L. 1998. Actual evapotranspiration and deficit: Biologically meaningful correlates of vegetation distribution across spatial scales. J. Biogeogr. 25:855-870.

Sunset. 1997. The 45 climate zones of the United States and Canada, p. 16-78, In: National garden book. Sunset Books, Menlo Park, CA.

Sunset. 2010. Find your U.S. Sunset climate zone. Sunset Publ., Menlo Park,
CA. 10 Feb. 2010. <http://www.sunset. com/garden/climate-zones/climatezones-intro-us-map-00400000036421/>.

Szalay, L., B. Timon, S. Németh, J. Papp, and M. Tóth. 2010. Hardening and dehardening of peach flower buds. HortScience 45:761-765.

Thompson, R.S., K.H. Anderson, and P.J. Bartlein. 2000. Atlas of relations between climatic parameters and distributions of important trees and shrubs in North America: Introduction and conifers. U.S. Geological Survey Professional Paper 1650-A.

Thornthwaite, C.W. 1948. An approach toward the rational classification of climate. Geogr. Rev. 38:55-94.

U.S. Census Bureau. 2003. Census 2000 PHC-T-29. Ranking tables for population of Metropolitan Statistical Areas, Micropolitan Statistical Areas, Combined Statistical Areas, New England City and Town Areas, and Combined New England City and Town Areas: 1990 and 2000. 8 Feb. 2010. <http://www. census.gov/population/www/cen2000/ phe-t29.html>.

U.S. Department of Agriculture. 1936. Atlas of American agriculture: Physical basis including land relief, climate, soils, and natural vegetation of the United States. U.S. Government Printing Office, Washington, DC.

U.S. Department of Agriculture. 1960. Plant hardiness zone map for the United States. USDA Misc. Publ. 814.

U.S. Department of Agriculture. 1965. Plant hardiness zone map for the United States (revised). USDA Misc. Publ. 814 (revised).

U.S. Department of Agriculture. 2010. Nursery software. 19 Feb. 2010. <http:// www.rma.usda.gov/tools/eplpps/>.

U.S. Department of Agriculture. 2012. USDA plant hardiness zone map. 1 Feb. 2012. <http://planthardiness.ars.usda.gov>

U.S. Geological Survey. 2006. National elevation dataset. 4 Mar. 2010. <http:// gisdata.usgs.gov/NED/>.

Väinölä, A., S. McNamara, and H. Pellett. 1997. Stem and flower bud hardiness of deciduous azaleas. J. Environ. Hort. 15:45-50.

Vogel, K.P., M.R. Schmer, and R.B. Mitchell. 2005. Plant adaptation regions: Ecological and climate classification of plant materials. Rangeland Ecol. Manag. 58:315-319.

Washington Wine Commission. 2010. Washingtonwine.org: The perfect climate for wine. 23 Feb. 2010. <http://www. washingtonwine.org $/>$. 
Widrlechner, M.P. 1994. Environmental analogs in the search for stress-tolerant landscape plants. J. Arboriculture 20: 114-119.

Widrlechner, M.P. 1997a. Hardiness zones in China. (Color map - scale ca. 1:16,360,000.) Iowa State University, Ames, IA.

Widrlechner, M.P. 1997b. Chinese forestry: Relationships worth cultivating, p. 38-47. In: N. Rose (ed.). Proc. Symp. on Landscape Plants: Exploration, breeding, evaluation, 27-29 June 1996. Landscape Plant Development Center, Chanhassen, MN.

Widrlechner, M.P. 1999. A zone map for mean annual moisture balance in the north central United States. Landscape Plant News 10(2):10-14.

Widrlechner, M.P. 2004. Insights into woody plant adaptation and practical applications. METRIA Proc. Vol. 13.9 Aug. 2010. <http://www.ces.ncsu.edu/fletcher/ programs/nursery/metria/metrial3/ widrlechner $/>$.

Widrlechner, M.P., E.R. Hasselkus, D.E. Herman, J.K. Iles, J.C. Pair, E.T. Paparozzi, R.E. Schutzki, and D.K. Wildung. 1992. Performance of landscape plants from Yugoslavia in the north central United States. J. Environ. Hort. 10:192-198.

Widrlechner, M.P. and J.K. Iles. 2002. A geographic assessment of the risk of naturalization of non-native woody plants in Iowa. J. Environ. Hort. 20: 47-56.

Widrlechner, M.P., R.E. Schutzki, V.Y. Yukhnovsky, and V.V. Sviatetsky. 2001. Collecting landscape trees and shrubs in Ukraine for the evaluation of aesthetic quality and adaptation in the north central United States. FAO/IPGRI Plant Genet. Resources Nwsl. 126:12-16.

Willmott, C.J. and S.M. Robeson. 1995. Climatologically aided interpolation (CAI) of terrestrial air temperature. Intl. J. Climatol. 15:221-229.

Wyman, D. and H.L. Flint. 1985. Plant hardiness-zone maps. Arnoldia 45(4):3234. 